\title{
Toward identifying specific roles for G-protein $\beta$ and $\gamma$ subunit variants in olfactory reception
}

\author{
Tamara Boto ${ }^{1,2}$ and Esther Alcorta ${ }^{1 *}$ \\ Departamento de Biologia Funcional (Genetica), Facultad de Medicina, Universidad de Oviedo, Oviedo, Spain \\ ${ }^{2}$ Department of Neuroscience, The Scripps Research Institute, Jupiter, FL, USA \\ *Correspondence: ealcorta@uniovi.es \\ Edited by: \\ Dieter Wicher, Max Planck Institute for Chemical Ecology, Germany \\ Reviewed by: \\ Ewald Grosse-Wilde, Max Planck Institute for Chemical Ecology, Germany
}

\section{A commentary on}

Expression profile of G-protein $\beta \gamma$ subunit gene transcripts in the mouse olfactory sensory epithelia

by Sathyanesan, A., Feijoo, A. A., Mehta, S. T., Nimarko, A. F., and Lin, W. (2013). Front. Cell. Neurosci. 7:84. doi: 10.3389/fncel.2013.00084

G-proteins mediate many cellular signaling processes; some are restricted to certain tissues or cell types, whereas others are involved in more general activities. For example, information regarding a change in the concentration of peptides, hormones, lipids, neurotransmitters, ions, odorants and tastants or an influx of photons to the eye can be transmitted to a cell via G-proteins.

Heterotrimeric G proteins are composed of three subunits: $G \alpha, G \beta$ and $G \gamma$. When activated, the $\mathrm{G} \alpha$ subunit binding GTP, and the G $\beta \gamma$ heterodimer act on their effectors. In both vertebrates and invertebrates, many genes encode different variants of each subunit. In mammals, 20 genes encode the $\mathrm{G} \alpha, 5 \mathrm{G} \beta$, and $12 \mathrm{G} \gamma$ subunits (Malbon, 2005; Dupre et al., 2009), and there is also a considerable amount of variability in more simple organisms, such as Drosophila melanogaster, with 6 genes for $\mathrm{G} \alpha, 3$ for $\mathrm{G} \beta$ and 2 for $\mathrm{G} \gamma$ (Wolfgang et al., 1990; Yarfitz et al., 1991; Schulz et al., 1999; Boto et al., 2010).

Expression studies generally offer basic information on the possible biological function of gene products and have been extensively applied to G-proteins in many species. Previous reports have confirmed that gene expression is cell specific in some cases. For example, in Drosophila, the Gaq-1 isoform (Lee et al., 1994) and the Gß76C subunit (Yarfitz et al., 1991) were found to be specifically expressed in photoreceptor cells, highlighting their role in phototransduction.

The possibility of relating specific expression of certain genes (specially for the less known $G \beta$ and $G \gamma$ subunits) with particular functions in a comprehensive way is both a very interesting and hot issue for very different fields (see for example, O’Neill et al., 2012; El-Haibi et al., 2013). The attempt to relate particular G $\beta$ and G $\gamma$ variants with olfactory reception tissues in mice is in the basis of the article by Sathyanesan et al. recently published in Frontiers in Cellular Neuroscience (2013, 7, 84).

In many vertebrates, olfactory reception is mediated by odorant receptors that belong to the G-protein-coupled receptor (GPCR) family (Mombaerts, 1999).

The expression pattern and functional roles for $\mathrm{G} \alpha$ proteins in olfactory reception have been deeply studied. Golf was found to be highly and almost exclusively expressed in olfactory receptor neurons (ORNs) of the main olfactory epithelium (MOE) (Jones and Reed, 1987), and a lack of Go in the vomeronasal organ (VNO) of mice elicits behavioral deficits (Chamero et al., 2011). However, the G $\beta \gamma$ subunits are not well-studied in mice, and only a few reports refer to the gene or protein expression of particular variants (Kulaga et al., 2004; Lin et al., 2007; Kerr et al., 2008; Li et al., 2013).

The G $\beta \gamma$ heterodimer is a functional structure that, unlike $\mathrm{G} \alpha$, does not change its conformational state when it dissociates from the heterotrimer. In vitro studies show a high variability of possible $\mathrm{G} \beta$ and $\mathrm{G} \gamma$ combinations, though the possibilities are more restricted in the native situation (Milligan and Kostenis, 2006).

In their paper in Frontiers in Cellular Neuroscience, Sathyanesan et al. (2013) performed a comprehensive study of the expression pattern of all G $\beta$ - and $\mathrm{G} \gamma$-encoding genes (17) in mice olfactory receptor epithelia, MOE and $\mathrm{VNO}$, in adult animals and also at different postnatal stages.

To this end, the researchers analyzed gene expression by RT-PCR and quantitative PCR using RNA extracted from both organs and designing specific primers for each $G \beta$ and $G \gamma$ subunit based on the $3^{\prime}$ UTR region in an attempt to overcome possible homology. The authors reported strong expression of the $\beta 1, \gamma 8$, and $\gamma 13$ genes in MOE, confirming previous results from other studies (Lin et al., 2007; Kerr et al., 2008), and also detected for the first time the expression of G $\beta 2,4$ and 5 and $G \gamma 2,3,5,10,11$, and 12 in this tissue. A quantitative analysis confirmed that $\beta 1$, $\gamma 8$ and $\gamma 13$ are the most abundant transcripts in the main olfactory epithelium of the mouse. Sathyanesan et al. similarly analyzed the expression of the $G \beta$ and $G \gamma$ subunits in VNO, and their results showed the expression of only G $\beta 1$ among the G $\beta$ group (and perhaps a very weak signal for $\mathrm{G} \beta 2$ ), and the strong presence of $\mathrm{G} \gamma 2,3,8$, and 13.

These data are based on the total RNA present in the organs. Thus, for further detail on the presence of distinct G proteins in different cell types in these olfactory organs, the authors performed in situ RNA hybridization experiments (RISH) to localize the $G \beta$ and $G \gamma$ transcripts to specific cells.

Although the RISH results did not consistently agree with the data from 
PCR experiments, as explained in the manuscript, such a situation can be due to the different sensitivities of the techniques or to the inherent technical difficulties of each. Nevertheless, the RISH data are reliable, considering that they show the most restrictive results. G $\beta 1$ appears to be the only variant expressed in MOE and VNO olfactory receptor neurons. With regard to G $\gamma$ subunits, some expression specificity was detected, as $\mathrm{G} \gamma 2$ and $\mathrm{G} \gamma 12$ were only localized to supporting cells. The authors performed double-labeled experiments to show that, in a considerable proportion of neurons in MOE, Golf and G $\gamma 13$ are expressed in the same cells, as are $\mathrm{G} \beta 1$ and G $\gamma 13$. Therefore, Sathyanesan et al. propose that these three subunits may be part of the same heterotrimer.

The authors also show convincing results regarding specific expression, depending on the cell type, of the $G \gamma$ subunits in VNO. VNO sensory neurons differentially express two types of $\mathrm{G} \alpha$ proteins: Gi2 in the apical layer and Go in the basal layer (Jia and Halpern, 1996). Sathyanesan et al. found 4 types of $\mathrm{G} \gamma$ in VNO: $G \gamma 2,3,8$, and 13. Although all are expressed in the Gi2 layer, only was found to $G \gamma 8$ localize to the basal Go layer of neurons.

Further experiments testing the cellular location and protein interactions will be necessary to confirm these data, but the finding of gene expression specificity for some $G \beta$ and $G \gamma$ subunits is an important step toward unraveling olfactory transduction in mammals and the role of G-proteins in the development of olfactory reception tissues.

\section{ACKNOWLEDGMENTS}

We thank the support of the Spanish Ministry of Science and Innovation (BFU2008-01256), FEDER funds, Principado de Asturias (PCTI COF09$01 \mathrm{y}$ SV-PA-13-ECOEMP-51) and the University of Oviedo (UNOV-12-MA11). Tamara Boto was a FPU fellow of the Spanish Ministry of Education and Culture.

\section{REFERENCES}

Boto, T., Gomez-Diaz, C., and Alcorta, E. (2010). Expression analysis of the 3 G-protein subunits, Galpha, Gbeta, and Ggamma, in the olfactory receptor organs of adult Drosophila melanogaster. Chem. Senses 35, 183-193. doi: 10.1093/chemse/bjp095

Chamero, P., Katsoulidou, V., Hendrix, P., Bufe, B., Roberts, R., Matsunami, H., et al. (2011). G protein $\mathrm{G}(\mathrm{alpha}) \mathrm{o}$ is essential for vomeronasal function and aggressive behavior in mice. Proc. Natl. Acad. Sci. U.S.A. 108, 12898-12903. doi: 10.1073/pnas.1107770108

Dupre, D. J., Robitaille, M., Rebois, R. V., and Hebert, T. E. (2009). The role of Gbetagamma subunits in the organization, assembly, and function of GPCR signaling complexes. Annu. Rev. Pharmacol. Toxicol. 49, 31-56. doi: 10.1146/annurev-pharmtox-061008103038

El-Haibi, C. P., Sharma, P., Singh, R., Gupta, P., Taub, D. D., Singh, S., et al. (2013). Differential G protein subunit expression by prostate cancer cells and their interaction with CXCR5. Mol. Cancer 12, 64. doi: 10.1186/1476-4598-12-64

Jia, C., and Halpern, M. (1996). Subclasses of vomeronasal receptor neurons: differential expression of $\mathrm{G}$ proteins (Gi alpha 2 and $\mathrm{G}$ (o alpha)) and segregated projections to the accessory olfactory bulb. Brain Res. 719, 117-128. doi: 10.1016/00068993(96)00110-2

Jones, D. T., and Reed, R. R. (1987). Molecular cloning of five GTP-binding protein cDNA species from rat olfactory neuroepithelium. J. Biol. Chem. 262, 14241-14249.

Kerr, D. S., Von Dannecker, L. E., Davalos, M., Michaloski, J. S., and Malnic, B. (2008). Ric8 B interacts with $G$ alpha olf and $G$ gamma 13 and co-localizes with $G$ alpha olf, $G$ beta 1 and G gamma 13 in the cilia of olfactory sensory neurons. Mol. Cell. Neurosci. 38, 341-348. doi: 10.1016/j.mcn.2008.03.006

Kulaga, H. M., Leitch, C. C., Eichers, E. R., Badano, J. L., Lesemann, A., Hoskins, B. E., et al. (2004). Loss of BBS proteins causes anosmia in humans and defects in olfactory cilia structure and function in the mouse. Nat. Genet. 36, 994-998. doi: $10.1038 / \mathrm{ng} 1418$

Lee, Y. J., Shah, S., Suzuki, E., Zars, T., Oday, P. M., and Hyde, D. R. (1994). The Drosophila dgq gene encodes a $\mathrm{G} \alpha$ protein that mediates phototransduction. Neuron 13, 1143-1157. doi: 10.1016/0896-6273(94)90052-3

Li, F., Ponissery-Saidu, S., Yee, K. K., Wang, H., Chen, M. L., Iguchi, N., et al. (2013).
Heterotrimeric G protein subunit Ggamma13 is critical to olfaction. J. Neurosci. 33, 7975-7984. doi: 10.1523/JNEUROSCI.5563-12.2013

Lin, W., Margolskee, R., Donnert, G., Hell, S. W., and Restrepo, D. (2007). Olfactory neurons expressing transient receptor potential channel M5 (TRPM5) are involved in sensing semiochemicals. Proc. Natl. Acad. Sci. U.S.A. 104, 2471-2476. doi: 10.1073/pnas.0610201104

Malbon, C. C. (2005). G proteins in development. Nat. Rev. Mol. Cell Biol. 6, 689-701. doi: $10.1038 / \mathrm{nrm} 1716$

Milligan, G., and Kostenis, E. (2006). Heterotrimeric G-proteins: a short history. Br. J. Pharmacol. 147, S46-S55. doi: 10.1038/sj.bjp.0706405

Mombaerts, P. (1999). Seven-transmembrane proteins as odorant and chemosensory receptors. Science 286, 707-711. doi: 10.1126/science.286. 5440.707

O’Neill, P. R., Karunarathne, W. K., Kalyanaraman, V., Silvius, J. R., and Gautam, N. (2012). Gprotein signaling leverages subunit-dependent membrane affinity to differentially control $\beta \gamma$ translocation to intracellular membranes. Proc. Natl. Acad. Sci. U.S.A. 109, E3568-E3577. doi: 10.1073/pnas.1205345109

Sathyanesan, A., Feijoo, A. A., Mehta, S. T., Nimarko, A. F., and Lin, W. (2013). Expression profile of Gprotein $\beta \gamma$ subunit gene transcripts in the mouse olfactory sensory epithelia. Front. Cell. Neurosci. 7:84. doi: 10.3389/fncel.2013.00084

Schulz, S., Huber, A., Schwab, K., and Paulsen, R. (1999). A novel G gamma isolated from Drosophila constitutes a visual G protein gamma subunit of the fly compound eye. J. Biol. Chem. 274, 37605-37610. doi: 10.1074/jbc.274.53.37605

Wolfgang, W. J., Quan, F., Goldsmith, P., Unson, C., Spiegel, A., and Forte, M. (1990). Immunolocalization of G-protein alpha-subunits in the Drosophila CNS. J. Neurosci. 10, 1014-1024.

Yarfitz, S., Niemi, G. A., McConnell, J. L., Fitch, C. L., and Hurley, J. B. (1991). A G-beta protein in the Drosophila compound eye is different from that in the brain. Neuron 7, 429-438. doi: 10.1016/0896-6273(91)90295-B

Received: 12 June 2013; accepted: 28 June 2013; published online: 17 July 2013.

Citation: Boto T and Alcorta E (2013) Toward identifying specific roles for $G$-protein $\beta$ and $\gamma$ subunit variants in olfactory reception. Front. Cell. Neurosci. 7:114. doi: 10.3389/fncel.2013.00114

Copyright (C) 2013 Boto and Alcorta. This is an openaccess article distributed under the terms of the Creative Commons Attribution License, which permits use, distribution and reproduction in other forums, provided the original authors and source are credited and subject to any copyright notices concerning any third-party graphics etc. 